\title{
THE AMERICAN COMMISSION ON SCIENTIFIC NOMENCLATURE IN ENTOMOLOGY
}

The disturbed condition of the world during the last few years has interfered with the activities of the International Commission on Zoological Nomenclature and there is no prospect that this Commission will again function successfully for several years to come. Entomologists in the United States have felt that this situation should not be allowed entirely to stifle progress in the development of nomenclature and the clarification of nomenclatorial problems. At the meetings of the Entomological Society of America and the American Association of Economic Entomologists in San Francisco, in December, 1941, a plan was adopted which called for the establishment of an American Commission on Scientific Nomenclature in Entomology.

In accord with the terms of this plan, Mr. C. F. W. Muesebeck and Professor G. F. Ferris were appointed to organize the Commission. That organization has now been completed and the Commission is ready to function. It includes Prof. J. C. Bradley, of Cornell University; Mr. W. J. Brown and Mr. G. Stuart Walley, of the Division of Entomology of the Department of Agriculture of Canada; Prof. G. F. Ferris, of Stanford University; Prof. T. H. Hubbell, of the University of Florida; Prof. H. B. Hungerford, of the University of Kansas ; Dr. E. G. Linsley, of the University of California; Prof. Clarence E. Mickel, ur the University of Minnesota; Mr. C. F. W. Muesebeck and Mr. P. W. Oman, of the United States Bureau of Entomology and Plant Quarantine; Prof. A. G. Richards, Jr., of the University of Pennsylvania; Dr. Herbert H. Ross, of the State Natural History Survey of Illinois ; Prof. C. W. Sabrosky, of the State Agricultural College of Michigan; Dr. R. L. Usinger, of the College of Agriculture of California. Prof. G. F. Ferris has been elected as Chairman.

The Commission will receive, consider and advise upon such nomenclatorial problems as are presented to it. All acts of the Commission will be in harmony with the International Rules of Zoological Nomenclature, although recommendations for the 
clarification, extension and improvement of these rules may be made. The Commission will report to the two parent societies at their next annual meeting. Communications concerning matters within the province of the Commission may be addressed to any of its members. 


\section{$2 \mathrm{BHL}$ Biodiversity Heritage Library}

1942. "The American Commission on Scientific Nomenclature in Entomology." Journal of the New York Entomological Society 50, 293-294.

View This Item Online: https://www.biodiversitylibrary.org/item/206025

Permalink: https://www.biodiversitylibrary.org/partpdf/178293

\section{Holding Institution}

Smithsonian Libraries

\section{Sponsored by}

Biodiversity Heritage Library

\section{Copyright \& Reuse}

Copyright Status: In Copyright. Digitized with the permission of the rights holder Rights Holder: New York Entomological Society License: http://creativecommons.org/licenses/by-nc/3.0/ Rights: https://www.biodiversitylibrary.org/permissions/

This document was created from content at the Biodiversity Heritage Library, the world's largest open access digital library for biodiversity literature and archives. Visit BHL at https://www.biodiversitylibrary.org. 